\title{
Learning orientation impact, innovativeness and business performance in Croatian companies
}

\author{
Helena Šlogar \\ Libertas International University, Zagreb, Croatia \\ https://orcid.org/0000-0002-7240-1140
}

\begin{abstract}
This study explores whether certain changes in the model of the impact that learning orientation (LO) had on innovativeness and business performance in Croatian companies occurred in the period 2016-2019. Regression and covariance analysis was used to analyse the collected data. According to the results obtained, the impact of learning orientation and its components (commitment to learning, shared vision, openmindedness and intra-organizational knowledge sharing) on innovativeness (product innovativeness, process innovativeness and business system innovativeness) did not change statistically significantly in the period 2016-2019. The same trend was observed with respect to business performance. In this period, a statistically significant change was identified in the effect of commitment to learning and open-mindedness on product innovativeness, and in the effect of open-mindedness on business system innovativeness. Likewise, the effect of commitment to learning, open mindedness and intra-organizational knowledge sharing within the company on the qualitative effects of business performance also changed. Empirical results provide significant theoretical and managerial implications in implementing a learning orientation with the aim of increasing companies' competitiveness in the market.
\end{abstract}

\section{Keywords}

innovativeness, learning orientation, business performance, Croatian companies

\section{Introduction}

Over the past few decades, many researchers have studied the impact of learning orientation as a purposeful use of knowledge in production, management, and value creation that affects a company's competitive advantage (Senge, 1990; Calantone, Cavusgil \& Zhao, 2002; Nybakk, 2012). Reasons justifying such an approach can be found in collecting, processing and disseminating information about customers, competitors and new products, technologies, markets and other sources, thus creating knowledge that allows managers to make business decisions faster. Today, we understand innovation in a broader context and talk about an innovative culture that stimulates new work and organizational processes in the enterprise. In this sense, when employees in a company develop an innovative business activity, they reveal their approach, values and principles on which they are based including the commitment to learning, shared vision, open-mindedness and intraorganizational knowledge sharing (Calantone et al., 2002). The interrelationships between learning orientation and enterprise innovativeness are an essential research area for scientists in the literature on strategy and management. The aim of this research was to conduct a longitudinal study of the impact among learning orientation, innovativeness and business performance in Croatian companies, and to determine the occurrence of changes in impact over a span of three years (2016 and 2019). In this regard, research questions are asked: (1) Is there a direct impact of learning orientation on innovativeness 
and business performance in Croatian companies? and (2) How much does it change over a span of three years? This research embraced the approach advocated by Oslo Manual (2005), which used a three-year time frame to understand the changes in innovation developments.

Learning-oriented firms can adapt more quickly to the market, anticipate changes in the environment, and be more innovative than their competitors (Slater \& Narver, 1995). The focus on learning is based on a long-term strategic orientation carried out by creating and using knowledge, which increases the motivation of employees, their creativity and innovativeness in the development of new products (Calantone et al., 2002). In a number of studies, learning orientation is cited as a key precursor to innovation development (Hult, Hurley \& Knight, 2004; Rhee, Park \& Lee, 2010), and key attributes are the goal and nature of innovation; types of innovation; stages in innovation development, social context; funds for innovation and others (Baregheh, Rowley \& Sambrook, 2009). The literature discusses various aspects of learning orientation such as organizational values that influence managers' decisions about whether a company will promote the concept of organizational learning (Sinkula, Baker \& Noordewier, 1997); or how to achieve dynamic learning (Calantone et al., 2002) and to encourage the use of new techniques and procedures by creating and using knowledge (Sinkula et al., 1997; Lee \& Tsai, 2005). In a study, Lee and Tsai (2005) confirm that learning orientation is associated with business innovation and collaborative business level, thereby promoting innovation and improving business performance.

An approach to learning and knowledge sharing with managerial support towards organizational creativity is an important process factor that provides the quality needed to develop innovation in an organization (Wang, 2008; Tajeddini \& Mueller, 2009). A study by Calantone et al. (2002) identifies that business success is achieved by a shared vision that leads to a culture of trust and knowledge sharing that allows for an increased level of business performance. Open-mindedness emphasizes that employee personality can be a determinant of a particular project's success (Calantone et al. 2002), such as examining the role of the Internet in knowledge creation (Nguyen \& Barrett 2006). Moreover, the main attention needs to be focused on the intra-organizational knowledge sharing in all departments through the systematic review and structuring of information (Calantone et al., 2002). More specifically, when considering a learning orientation, it is necessary to emphasize the role and quality of knowledge that determine a company's success or failure (Senge, 1990). In this regard, various studies indicate that the learning orientation is also influenced by the entrepreneur's behaviour, specific characteristics of the company, such as its size or industrial sector (Salim \& Sulaiman, 2011; D'Angelo \& Presutti, 2019). The study was organized as follows. A literature review was conducted to identify fundamental questions about learning orientation, innovativeness, and business performance. Then the hypothesis was formed, followed by a description of the research methods and the research results. Theoretical and practical implications and conclusion are also stated.

\section{Literature review}

According to Senge (1990) learning orientation is an organizational characteristic where the acquired knowledge is applied systematically and effectively, thus setting the framework for relationships with customers and competitors. Hurley and Hult (1998) state that a higher level of innovation is associated with companies' cultures that emphasize learning, participatory decisionmaking, and development. The importance of individual and organizational learning as aspects influencing company growth was extensively discussed (Koryak, Mole, Lockett, Hayton, Ucbasaran \& Hodgkinson 2015). The Cosenz and Noto (2018) study states that entrepreneurial learning is a crucial process for acquiring the strategic management competencies needed to start new businesses and achieve success. Learning orientation includes a commitment to vision sharing, openness and information sharing, commitment to learning and knowledge enhancement based on market orientation leading to new market research, technology advancement, product and service development (Slater \& Narver, 1994). A number of studies state that the focus on learning is the concept of knowledge creation and use activities in an organization that lead to product innovation and increased market competitiveness (Damanpour, 1991; Day, 1994; Baker \& Sinkula, 1999).

Vij and Farooq (2014) point out that a learning orientation has a positive effect on company's business results. New ideas emerge in the mutual interactions of new associates who select those 
most likely to achieve the maximum innovation effect. According to the results of older research communicating a shared vision to facilitate the implementation of creative ideas and overcoming problems to be solved is an important basis for proactive learning in the organization (Sinkula et al. 1997; Hurley \& Hult 1998; Calantone et al. 2002).

In a study by Jiménez-Jiménez and CegarraNavarro (2007), organizational learning has a positive effect on business performance. It also encourages processes of collaboration, assignment, and integration among team members and expands the new knowledge creation (Lumpkin \& Lichtenstein, 2005). Organizational learning includes teams in learning processes, and group knowledge in start-up teams is significantly associated with business success (Chandler \& Lyon, 2009). Furthermore, Sanzo, Santos, García and Trespalacios (2012) investigated the relationship between organizational learning, operational marketing ability and performance and confirmed the positive impact on performance in Spanish industrial companies. Real, Roldan and Leal (2014) state that the impact of orientation on learning is greater in small and medium-sized enterprises than in large ones. Stelmaszczyk (2020) finds that absorptive capacity is most affected by two dimensions of learning orientation: commitment to learning and openmindedness.

Furthermore, Wang (2008) reveals on a sample of British companies that learning orientation mediates in relation to entrepreneurial orientation and that it must exist in order to maximize performance. However, Michna (2009) suggests that Polish SMEs that reach a higher level of organizational learning are likely to achieve greater effectiveness. Interestingly, Kharabsheh, Jarrar and Simeonova (2015) show that learning orientation is the most important factor for better organizational performance. Besides, there are significant links between learning orientation and organizational performance of the company.

Previous research has revealed a positive relationship between learning orientation and innovativeness (Calantone et al., 2002; Hult et al., 2004; Keskin, 2006). In a study by Lin et al. (2008), innovativeness, along with learning orientation, functions as a key success factor in technology-intensive firms in Taiwan. On the other hand, Rhee et al. (2010) confirmed the significant impact of learning orientation on small business innovativeness in South Korea. In addition, learning-oriented companies are able to develop intangible assets that are more innovative (Rhee et al., 2010). Similarly, Nasution, Mavondo, Matanda and Ndubisi (2011) suggest that the interaction of learning orientation and human resource practices have a significant impact on the development of innovation.

Furthermore, Salim and Sulaiman (2011) pointed to a positive impact of organizational learning on innovation. Likewise, a positive relationship exists between innovation and the performance of SMEs operating in the ICT industry in Malaysia. Suliyanto and Rahab (2012) confirm that learning orientation plays a mediating role in the relationship between market orientation and innovativeness. Likewise, the results show that innovativeness affects business performance. The findings suggest that companies should strengthen their learning and innovativeness orientation to improve business performance. Moreover, Goh, Elliott and Quon, (2012) support a positive relationship between learning ability and organizational performance. This has significant implications for justifying investment in capacity building in organizations. In a study by Acs, Audretsch and Lehmann (2013) human capital serves not only as a guide for the dissemination of knowledge, but also for innovative activities and improved economic performance through resource allocation.

Aziz and Omar (2013) show that shared knowledge and vision have directly influenced the innovation capabilities of SMEs and are crucial factors for improving business results. Rahab (2012) finds that companies should strengthen their innovativeness and learning orientation to improve business performance. The results show that company innovativeness has a positive effect on company performance, while the focus on learning has a positive effect on company innovativeness. On the other hand, it explains that a learning organization cannot directly improve its performance and that there are other factors that create relationships between organizational learning and business performance. Hakala (2013) confirms the relationship between learning orientation and entrepreneurial orientation and that the effects mediate the profitability of Finnish software companies. In a study conducted by Alegre and Chiva (2013) a positive relationship between innovation efficiency based on strategic human resource management, knowledge and information technology was identified in a sample 
of French biotechnology SMEs. Dülger, Alpay, Y1lmaz and Bodur (2014) indicate that differentiation strategy, internally oriented learning, and market-oriented learning have significant effects on different dimensions of innovativeness in business operations.

Hussain, Shah and Khan (2016) examine the relationship between learning orientation and business performance in SMEs. They found that the focus on learning was positively and significantly related to the organizational performance of the company. Furthermore, Mahmoud, Blankson, Owusu-Frimpong, Nwankwo, Tran and Trang (2016) show in the context of a developing country that learning orientation has a significant impact on innovation that mediates in relation to business performance. Learning-oriented companies tend to reduce administrative costs by using high technology and new communication channels. Unlike other studies, this study showed that learning orientation has no effect on the relationship between market orientation and organizational performance of SMEs (Beneke, Blampied, Dewar \& Soriano, 2016).

Nurhasanah and Murwatiningsih (2018) found that companies that apply learning orientation, innovativeness, and competitive advantage can improve marketing performance. Furthermore, Ismail, Hamid, Senik, Othman and Juhdi (2018) explore the role of innovativeness and a focus on learning in the effects of internationalization of SMEs. Vega Martinez, Martinez Serna and Montoya (2020) find that there is a significant relationship between commitment to learning and a shared vision, and competitiveness and organization performance. The Phorncharoen's study (2020) confirms that learning orientation had a positive impact on innovativeness $(p<0.05)$ in the enterprise. Likewise, Huan, Phong and Giang (2020) have shown that there is a relationship between learning orientation and business model innovation in the tourism sector. Ullah, Mushtaq, Puhakka and Iqbal (2020) explore the mediating role of employee absorptive abilities between learning orientation and market orientation.

Based on a literature review, the following hypothesis was proposed:

$\mathrm{H}$ : Learning orientation has a positive and direct impact on the innovativeness and business performance of the company and this impact did not change significantly in 2019 compared to 2016.

\section{Research methodology}

A longitudinal study was conducted based on the same model, the same hypotheses, the same survey, and subsets of the 2016 and 2019 samples to be compatible for comparison. Results of the previous study were published in papers (Šlogar \& Bezić, 2020). Learning orientation and commitment to learning, shared vision, open mindedness, and intra-organizational knowledge sharing exchange within the organization as its dimensions are included in the model as independent variables (Calantone et al., 2002). A five-point Likert scale was used for measurement. Innovativeness and its dimensions (product innovation, process innovativeness and business system innovativeness (Nybakk, 2012) and business performance, comprising dimensions quantitative and qualitative effects served as dependent variables. Answers to the survey questions were scored on a five-point Likert scale.

Only companies from the Croatian Chamber of Commerce database that participated in the 2016 and 2019 surveys were selected for the longitudinal survey to make the comparison as reliable as possible. Finally, 101 companies participating in the 2016 survey and 101 companies participating in the 2019 survey were selected to constitute the sample. An online survey questionnaire was used to collect data in two different periods: October to December 2016 and October 2019 to January 2020. Power analysis found that on a sample of 101 companies for a 95\% confidence level and a test power of $90 \%$, a correlation coefficient greater than 0.30 would be statistically significant which is the expected correlation between independent and dependent variables based on a 2016 survey.

Descriptive statistics shows that there are no significant deviations of the mean value (Mean) from the median value (Median), so the parametric methods regression analysis and covariance analysis are applied. Regression analysis examined a statistically significant correlation between independent and dependent variables in 2016 and 2019. Covariance analysis (ANCOVA) examined whether the impact of learning orientation and its four dimensions on innovativeness and business performance in the period 2016 - 2019 had changed. A parallel representation of regression directions from 2016 and 2019 was used for graphical representation. 


\section{Research results}

In this chapter, the analysis of the survey results will be presented. Complex data will be analysed with a table or graph.

Table 1 Descriptive statistics of variables included in model 2016 and $2019(\mathrm{~N}=101)$

\begin{tabular}{|c|c|c|c|c|c|}
\hline 2016 & Mean & Median & Min & Max & Std.Dev \\
\hline $\begin{array}{l}\text { Learning } \\
\text { orientation }\end{array}$ & 83.7 & 84.0 & 54 & 109 & 13.29 \\
\hline $\begin{array}{l}\text { Commitment to } \\
\text { learning }\end{array}$ & 19.6 & 20.0 & 8 & 25 & 3.91 \\
\hline Shared vision & 19.2 & 19.0 & 9 & 25 & 3.69 \\
\hline $\begin{array}{l}\text { Open } \\
\text { mindedness }\end{array}$ & 18.7 & 18.0 & 9 & 25 & 3.53 \\
\hline $\begin{array}{l}\text { Intra- } \\
\text { organizational } \\
\text { knowledge } \\
\text { sharing }\end{array}$ & 22.2 & 22.0 & 12 & 30 & 4.18 \\
\hline Innovativeness & 56.9 & 57.0 & 25 & 79 & 11.93 \\
\hline $\begin{array}{l}\text { Product } \\
\text { innovation }\end{array}$ & 20.9 & 22.0 & 6 & 30 & 5.36 \\
\hline $\begin{array}{l}\text { Process } \\
\text { innovativeness }\end{array}$ & 14.4 & 15.0 & 4 & 20 & 3.95 \\
\hline $\begin{array}{l}\text { Business } \\
\text { system } \\
\text { innovativeness }\end{array}$ & 17.4 & 17.0 & 11 & 24 & 3.61 \\
\hline $\begin{array}{l}\text { Business } \\
\text { performance }\end{array}$ & 59.3 & 58.0 & 39 & 77 & 9.03 \\
\hline $\begin{array}{l}\text { Business } \\
\text { performance - } \\
\text { Quantitative } \\
\text { effects }\end{array}$ & 23.6 & 23.0 & 12 & 33 & 4.27 \\
\hline $\begin{array}{l}\text { Business } \\
\text { performance - } \\
\text { Qualitative } \\
\text { effects }\end{array}$ & 31.8 & 32.0 & 20 & 45 & 5.41 \\
\hline 2019 & Mean & Median & Min & Max & Std.Dev \\
\hline $\begin{array}{l}\text { Learning } \\
\text { orientation }\end{array}$ & 85.8 & 87.0 & 54 & 103 & 10.85 \\
\hline $\begin{array}{l}\text { Commitment to } \\
\text { learning }\end{array}$ & 20.0 & 20.0 & 11 & 25 & 2.85 \\
\hline Shared vision & 19.9 & 20.0 & 10 & 25 & 3.24 \\
\hline
\end{tabular}

\begin{tabular}{l|c|c|c|c|c}
\hline $\begin{array}{l}\text { Open } \\
\text { mindedness }\end{array}$ & 19.1 & 19.0 & 11 & 25 & 3.08 \\
\hline $\begin{array}{l}\text { Intra- } \\
\text { organizational } \\
\text { knowledge } \\
\text { sharing }\end{array}$ & 22.8 & 23.0 & 11 & 30 & 3.54 \\
\hline Innovativeness & 59.7 & 60.0 & 27 & 80 & 13.36 \\
\hline $\begin{array}{l}\text { Product } \\
\text { innovation }\end{array}$ & 22.6 & 23.0 & 6 & 30 & 5.92 \\
\hline $\begin{array}{l}\text { Process } \\
\text { innovativeness }\end{array}$ & 14.8 & 16.0 & 6 & 20 & 4.11 \\
\hline $\begin{array}{l}\text { Business } \\
\text { system } \\
\text { innovativeness }\end{array}$ & 18.5 & 19.0 & 9 & 25 & 4.23 \\
\hline $\begin{array}{l}\text { Business } \\
\text { performance }\end{array}$ & 61.5 & 61.0 & 44 & 80 & 9.67 \\
\hline $\begin{array}{l}\text { Business } \\
\text { performance - } \\
\text { Quantitative } \\
\text { effects }\end{array}$ & 24.0 & 24.0 & 16 & 31 & 3.85 \\
\hline $\begin{array}{l}\text { Business } \\
\text { performance } \\
\text { Qualitative } \\
\text { effects }\end{array}$ & 33.7 & 33.0 & 22 & 45 & 6.18 \\
\hline
\end{tabular}

Source: the author

Table 1 shows the basic statistical indicators for the variables included in the survey and for the values obtained in 2016 and 2019. The values of these variables are the answers to the questions from the survey scored on a five-point Likert scale. The results show that there is no significant difference between the arithmetic mean (Mean) and the median value (Median) which means that the values of the variables do not deviate significantly from the normal distribution in the two observed periods. Thus, it is justified to apply regression analysis and covariance analysis in further statistical processing.

Table 2 Regression Analysis - The impact of independent variables on innovativeness in 2016 and 2019.

\begin{tabular}{|c|c|c|c|c|c|c|c|c|}
\hline \multicolumn{9}{|c|}{ Dependent Variable: Innovativeness } \\
\hline \multirow{2}{*}{ Independent variable } & \multicolumn{4}{|c|}{2016} & \multicolumn{4}{|c|}{2019} \\
\hline & $\mathrm{R}$ & SE & $F(1.99)$ & $\mathrm{p}$ & $\mathrm{R}$ & SE & $F(1.99)$ & $\mathrm{p}$ \\
\hline Learning orientation & 0.692 & 0.073 & 91.083 & $<0.001$ & 0.770 & 0.064 & 144.286 & $<0.001$ \\
\hline Commitment to learning & 0.583 & 0.082 & 51.021 & $<0.001$ & 0.540 & 0.085 & 40.801 & $<0.001$ \\
\hline Shared vision & 0.640 & 0.077 & 68.678 & $<0.001$ & 0.751 & 0.066 & 128.203 & $<0.001$ \\
\hline Open mindedness & 0.642 & 0.077 & 69.329 & $<0.001$ & 0.687 & 0.073 & 88.554 & $<0.001$ \\
\hline Intra-organizational knowledge sharing & 0.488 & 0.088 & 30.889 & $<0.001$ & 0.613 & 0.079 & 59.608 & $<0.001$ \\
\hline \multicolumn{9}{|c|}{ Dependent Variable: Product innovation } \\
\hline \multirow{2}{*}{ Independent variable } & \multicolumn{4}{|c|}{2016} & \multicolumn{4}{|c|}{2019} \\
\hline & $\mathrm{R}$ & SE & $F(1.99)$ & $\mathrm{p}$ & $\mathrm{R}$ & SE & $F(1.99)$ & $p$ \\
\hline Learning orientation & 0.611 & 0.080 & 58.914 & $<0.001$ & 0.717 & 0.070 & 104.969 & $<0.001$ \\
\hline Commitment to learning & 0.493 & 0.087 & 31.816 & $<0.001$ & 0.479 & 0.088 & 29.415 & $<0.001$ \\
\hline Shared vision & 0.562 & 0.083 & 45.797 & $<0.001$ & 0.721 & 0.070 & 107.375 & $<0.001$ \\
\hline
\end{tabular}




\begin{tabular}{|c|c|c|c|c|c|c|c|c|}
\hline Open mindedness & 0.616 & 0.079 & 60.385 & $<0.001$ & 0.670 & 0.075 & 80.606 & $<0.001$ \\
\hline Intra-organizational knowledge sharing & 0.428 & 0.091 & 22.192 & $<0.001$ & 0.555 & 0.084 & 44.045 & $<0.001$ \\
\hline \multicolumn{9}{|c|}{ Dependent Variable: Process innovativeness } \\
\hline \multirow{2}{*}{ Independent variable } & \multicolumn{4}{|c|}{2016} & \multicolumn{4}{|c|}{2019} \\
\hline & $\mathrm{R}$ & SE & $F(1.99)$ & $\mathrm{p}$ & $\mathrm{R}$ & SE & $F(1.99)$ & $\mathrm{p}$ \\
\hline Learning orientation & 0.664 & 0.075 & 78.259 & $<0.001$ & 0.662 & 0.075 & 77.112 & $<0.001$ \\
\hline Commitment to learning & 0.603 & 0.080 & 56.442 & $<0.001$ & 0.469 & 0.089 & 27.897 & $<0.001$ \\
\hline Shared vision & 0.596 & 0.081 & 54.568 & $<0.001$ & 0.639 & 0.077 & 68.169 & $<0.001$ \\
\hline Open mindedness & 0.556 & 0.084 & 44.291 & $<0.001$ & 0.588 & 0.081 & 52.378 & $<0.001$ \\
\hline Intra-organizational knowledge sharing & 0.490 & 0.088 & 31.332 & $<0.001$ & 0.567 & 0.083 & 46.836 & $<0.001$ \\
\hline \multicolumn{9}{|c|}{ Dependent Variable: Business system innovativeness } \\
\hline \multirow{2}{*}{ Independent variable } & \multicolumn{4}{|c|}{2016} & \multicolumn{4}{|c|}{2019} \\
\hline & $\mathrm{R}$ & SE & $F(1.99)$ & $\mathrm{p}$ & $\mathrm{R}$ & SE & $F(1.99)$ & $\mathrm{p}$ \\
\hline Learning orientation & 0.476 & 0.088 & 29.040 & $<0.001$ & 0.756 & 0.066 & 132.348 & $<0.001$ \\
\hline Commitment to learning & 0.365 & 0.094 & 15.250 & $<0.001$ & 0.575 & 0.082 & 48.786 & $<0.001$ \\
\hline Shared vision & 0.449 & 0.090 & 24.959 & $<0.001$ & 0.729 & 0.069 & 112.470 & $<0.001$ \\
\hline Open mindedness & 0.448 & 0.090 & 24.834 & $<0.001$ & 0.648 & 0.077 & 71.641 & $<0.001$ \\
\hline Intra-organizational knowledge sharing & 0.348 & 0.094 & 13.669 & $<0.001$ & 0.595 & 0.081 & 54.159 & $<0.001$ \\
\hline
\end{tabular}

In Table 2 the regression analysis results showed that in 2016 and 2019, the company's innovativeness was statistically significantly positively influenced by learning orientation, learning commitment, shared vision, open mind and intra-organizational knowledge sharing knowledge within the company $(\mathrm{p}<0.001)$. Second, in 2016 and 2019, product innovation was statistically significantly positively influenced by learning orientation, commitment to learning, shared vision, open mindedness and intra-organizational knowledge sharing within the company $(\mathrm{p}<0.001)$. Third, it was shown that in 2016 and 2019, the innovativeness of the process was statistically significantly and positively influenced by learning orientation and all four of its dimensions $(p<0.001)$. Fourth, it was shown that in 2016 and 2019, the business system innovativeness was statistically significantly and positively influenced by learning orientation, commitment to learning, shared vision, open mindedness and knowledge sharing within the company $(\mathrm{p}<0.001)$.

Table 3 Regression Analysis - The impact of independent variables on business performance in 2016 and 2019

\begin{tabular}{|c|c|c|c|c|c|c|c|c|}
\hline \multicolumn{9}{|c|}{ Dependent Variable: Business performance } \\
\hline \multirow{2}{*}{ Independent variable } & \multicolumn{4}{|c|}{2016} & \multicolumn{4}{|c|}{2019} \\
\hline & $\mathrm{R}$ & SE & $F(1,99)$ & p-level & $\mathrm{R}$ & SE & $F(1,99)$ & p-level \\
\hline Learning orientation & 0.666 & 0.075 & 79.089 & $<0.001$ & 0.655 & 0.076 & 74.282 & $<0.001$ \\
\hline Commitment to learning & 0.564 & 0.083 & 46.257 & $<0.001$ & 0.495 & 0.087 & 32.198 & $<0.001$ \\
\hline Shared vision & 0.678 & 0.074 & 84.112 & $<0.001$ & 0.715 & 0.070 & 103.770 & $<0.001$ \\
\hline Open mindedness & 0.628 & 0.078 & 64.396 & $<0.001$ & 0.541 & 0.085 & 40.933 & $<0.001$ \\
\hline Intra-organizational knowledge sharing & 0.406 & 0.092 & 19.534 & $<0.001$ & 0.458 & 0.089 & 26.245 & $<0.001$ \\
\hline
\end{tabular}


Dependent Variable: Business performance - Quantitative effects

\begin{tabular}{c|c|c|c|c|c|c|c|c}
\hline \multirow{2}{*}{ Independent variable } & \multicolumn{4}{|c}{2016} & \multicolumn{4}{c}{2019} \\
\cline { 2 - 9 } & $\mathrm{R}$ & $\mathrm{SE}$ & $\mathrm{F}(1,99)$ & $\mathrm{p}$-level & $\mathrm{R}$ & $\mathrm{SE}$ & $\mathrm{F}(1,99)$ & $\mathrm{p}$-level \\
\hline Learning orientation & 0.489 & 0.088 & 31.119 & $<0.001$ & 0.446 & 0.090 & 24.631 & $<0.001$ \\
\hline Commitment to learning & 0.364 & 0.094 & 15.132 & $<0.001$ & 0.306 & 0.096 & 10.224 & 0.002 \\
\hline Shared vision & 0.492 & 0.087 & 31.651 & $<0.001$ & 0.513 & 0.086 & 35.387 & $<0.001$ \\
\hline Open mindedness & 0.514 & 0.086 & 35.560 & $<0.001$ & 0.405 & 0.092 & 19.443 & $<0.001$ \\
\hline Intra-organizational knowledge sharing & 0.301 & 0.096 & 9.829 & 0.002 & 0.293 & 0.096 & 9.329 & 0.003 \\
\hline
\end{tabular}

\begin{tabular}{|c|c|c|c|c|c|c|c|c|}
\hline \multirow{2}{*}{ Independent variable } & \multicolumn{4}{|c|}{2016} & \multicolumn{4}{|c|}{2019} \\
\hline & $\mathrm{R}$ & SE & $F(1.99)$ & p-level & $\mathrm{R}$ & SE & $F(1.99)$ & p-level \\
\hline Learning orientation & 0.666 & 0.075 & 78.793 & $<0.001$ & 0.703 & 0.072 & 96.545 & $<0.001$ \\
\hline Commitment to learning & 0.606 & 0.080 & 57.425 & $<0.001$ & 0.563 & 0.083 & 45.830 & $<0.001$ \\
\hline Shared vision & 0.681 & 0.074 & 85.670 & $<0.001$ & 0.739 & 0.068 & 119.091 & $<0.001$ \\
\hline Open mindedness & 0.578 & 0.082 & 49.717 & $<0.001$ & 0.570 & 0.083 & 47.769 & $<0.001$ \\
\hline Intra-organizational knowledge sharing & 0.408 & 0.092 & 19.770 & $<0.001$ & 0.496 & 0.087 & 32.222 & $<0.001$ \\
\hline
\end{tabular}

In Table 3 the regression analysis results showed that in 2016 and 2019, business orientation was statistically significantly positively influenced by learning orientation, learning commitment, shared vision, open mindedness and intra-organizational knowledge sharing within the company $(\mathrm{p}<0.001)$. It was shown that in 2016 and 2019, the quantitative effects of business performance were statistically significantly positively influenced by learning orientation, commitment to learning, shared vision, open mindedness and knowledge sharing within the company $(\mathrm{p}<0.01)$. Third, it was shown that in 2016 and 2019, the qualitative effects of business performance were statistically significantly positively influenced by learning orientation and all its dimensions within the company $(\mathrm{p}<0.001)$.

Table 4 Analysis of Covariance (ANCOVA) Comparison of the impact of independent variables on innovativeness in 2016 and 2019

\begin{tabular}{c|c|c|c|c|c|c|c|c}
\hline \multirow{2}{*}{ Effect 2016 vs. 2019 } & \multicolumn{2}{|l|}{ Innovativeness } & \multicolumn{2}{l|}{ Product innovation } & \multicolumn{2}{c}{$\begin{array}{c}\text { Process } \\
\text { innovativeness }\end{array}$} & \multicolumn{2}{c}{$\begin{array}{c}\text { Business } \\
\text { system } \\
\text { innovativeness }\end{array}$} \\
\cline { 2 - 11 } & $\mathrm{F}$ & $\mathrm{p}$ & $\mathrm{F}$ & $\mathrm{p}$ & $\mathrm{F}$ & $\mathrm{p}$ & $\mathrm{F}$ & $\mathrm{p}$ \\
\hline Learning orientation & 1.892 & 0.170 & 3.075 & 0.081 & 0.030 & 0.862 & 2.745 & 0.099 \\
\hline Commitment to learning & 2.686 & 0.102 & 3.843 & 0.051 & 0.066 & 0.797 & 3.533 & 0.061 \\
\hline Shared vision & 1.246 & 0.265 & 2.334 & 0.128 & 0.091 & 0.763 & 2.144 & 0.144 \\
\hline Open mindedness & 3.177 & 0.076 & 4.582 & 0.033 & 0.088 & 0.765 & 3.876 & 0.050 \\
\hline Intra-organizational knowledge sharing & 2.254 & 0.134 & 3.406 & 0.066 & 0.019 & 0.888 & 3.136 & 0.078 \\
\hline
\end{tabular}

Source: the author

Table 4 shows the results of covariance analysis which tested the statistical difference between regression paths where there is no statistically significant difference between the impact of learning orientation, commitment to learning, shared vision, open mindedness and intra-organizational knowledge sharing within the company on innovativeness in 2016 and 2019 (p> 0.05 ). Second, it shows no statistically significant difference between the impact of learning orientation, shared vision and intra-organizational knowledge sharing within the company on 
product innovation in 2016 and 2019 ( $\mathrm{p}>0.05)$. A marginally statistically significant difference was found between commitment to learning and product innovation in 2016 and 2019 ( $p$ is approximately equal to 0.05 ), and a statistically significant difference between open mindedness and product innovation in 2016 and 2019 ( $\mathrm{p}<$ 0.05). Third, the results show no statistically significant difference between the impact of learning orientation, commitment to learning, shared vision, open mindedness and intra- organizational knowledge sharing within the company and process innovativeness in 2016 and 2019 ( $p>0.05$ ). Fourth, there is no statistically significant difference between the impact of learning orientation, commitment to learning, shared vision and knowledge sharing within the company and business system innovativeness in 2016 and 2019 ( $p>0.05$ ). At the same time, there is a marginally statistically significant difference between the impact of open mindedness and product innovation in 2016 and $2019(\mathrm{p}=0.05)$.

Table 5 Comparison of the impact of independent variables on business performance in 2016 and 2019

\begin{tabular}{l|l|l|l|l|l|l}
\hline \multirow{2}{*}{ Effect 2016 vs. 2019} & \multicolumn{2}{l}{ Business performance } & \multicolumn{2}{l}{$\begin{array}{l}\text { Business performance - } \\
\text { Quantitative effects }\end{array}$} & \multicolumn{2}{l}{$\begin{array}{l}\text { Business performance - } \\
\text { Qualitative effects }\end{array}$} \\
\cline { 2 - 8 } & $\mathrm{F}$ & $\mathrm{p}$ & $\mathrm{F}$ & $\mathrm{p}$ & $\mathrm{F}$ & $\mathrm{p}$ \\
\hline Learning orientation & 1.150 & 0.284 & 0.001 & 0.991 & 3.852 & 0.051 \\
\hline Commitment to learning & 1.876 & 0.172 & 0.086 & 0.768 & 4.758 & 0.030 \\
\hline Shared vision & 0.647 & 0.421 & 0.042 & 0.836 & 2.976 & 0.086 \\
\hline Open mindedness & 2.088 & 0.150 & 0.058 & 0.808 & 5.057 & 0.025 \\
\hline Intra-organizational knowledge sharing & 1.645 & 0.201 & 0.069 & 0.792 & 4.060 & 0.045 \\
\hline
\end{tabular}

Table 5 shows the covariance analysis results indicating no statistically significant difference between the impact of learning orientation, commitment to learning, shared vision, open mindedness and intra-organizational knowledge sharing within the company on business performance in 2016 and 2019 ( $p>0.05)$. Second, no statistically significant difference was found between the impact of learning orientation, learning commitment, shared vision, open mindedness and intra-organizational knowledge sharing within the company on the quantitative effects of business performance in 2016 and 2019 ( $>$ $>0.05$ ). Third, it is shown that there is no statistically significant difference between the impact of a shared vision on the qualitative effects of business performance in 2016 and 2019 (p> 0.05). A marginally statistically significant difference was found between the impact of learning orientation and the qualitative effects of business performance in 2016 and 2019 ( $p$ is approximately equal to 0.05 ). Also, there is a statistically significant difference among the impact of learning commitment, open mindedness and intra-organizational knowledge sharing within the company and the qualitative effects of business performance in 2016 and $2019(p<0.05)$.

Figure 1 shows that the score of responses related to the impact of learning orientation on company innovativeness was higher in 2016 than in 2019. The lines intersect near the score of 80 , which means that the values around the score of 80 are as frequent in in 2016 as in 2019.

Also, scores higher than 80 are more represented in 2019 than in 2016. As regards the answers related to the impact of learning orientation on business performance more answers with a higher score were recorded in 2016 than in 2019. Similarly, the lines intersect near the score of 80 , which means that the values around the score of 80 are as frequent in 2016 as in 2019. The results show more scores higher than 80 in 2019 in comparison to 2016.

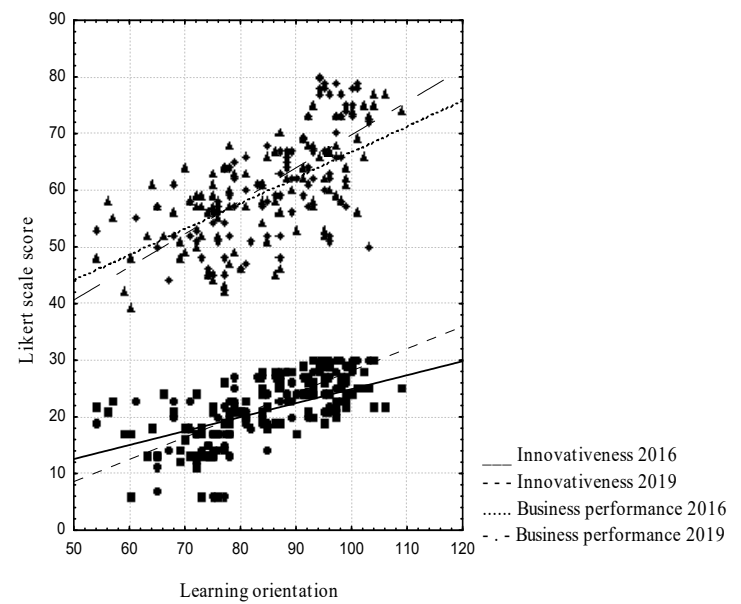

Figure 1 The impact of learning orientation on innovativeness and business performance

Source: the author 


\section{Discussion and conclusion}

The aim of this study was to investigate whether there are differences in the impact of learning orientation, innovativeness and business performance in the two observed periods depending on their context. In other words, this research examined the role of a particular environment in respect of how companies practice learning orientation and develop innovativeness in order to improve business performance. The findings confirm the hypothesis, thus providing further evidence that the learning orientation has a positive and direct impact on the innovativeness and company's business performance, and this impact did not change significantly in 2019 compared to 2016. A review of the literature allows for the conclusion that learning orientation and innovativeness are important for building company success in markets. Regardless of the existing investigation into the impact of learning orientation, innovativeness on performance, the results are insufficient, which emphasizes the need for further investigation in companies in the international market.

According to the results obtained, there are no significant changes in 2016 and 2019, which may indicate other factors that influence the relationships and are not included in this study depending on the specific management form. Therefore, companies need to encourage employees to share their knowledge within the company and thus improve their openness in order to increase business performance (Calantone et al., 2002). It can be concluded that learning orientation, as a result, also supports strong innovativeness, and therefore, a culture of learning and knowledge sharing should be developed within a company. This conclusion is interesting because, despite the efforts made by various companies in spreading the learning orientation, these efforts are insufficient for significant progress in innovativeness and business performance. The awareness of the learning orientation values and innovativeness should lead to serious changes in business operation, a task not easy to achieve in this turbulent time. Therefore, to effect the change of relationship among learning orientation, innovativeness and business performance more attention should be paid to how companies improve business performance.

The paper discusses the implications that include addressing the need for new mediating factors and influences to understand this complex relationship better. Research is also needed to increase our understanding of effectively developing the ability to learn and transform into innovation processes that are changing current ways of doing business. Likewise, this research advances the understanding of the learning orientation impact on innovativeness and business performance. Moreover, this study has implications for companies with the aim of increasing their innovativeness and performance. The conducted longitudinal study provides empirical evidence that supports the value of building learning orientation and the ability to innovate in enterprises. Practical implications state that innovativeness can be strengthened through organizational learning. Companies should link vision with employee learning abilities to increase business performance. The results suggest that company managers should develop a culture that includes learning orientation to support innovativeness that affects profitability. Companies' efforts to develop learning orientation and improve innovation processes should benefit all stakeholders.

As the business environment has become more dynamic, learning orientation and innovativeness are those important issues that executives need to develop. The interrelationships between learning orientation and enterprise innovativeness are an important research area for scholars exploring management, marketing, and strategy. The research results will help companies to increase efforts that should be synchronized with the development of learning orientation and innovativeness in order to increase profitability. The research results fill a gap in current learningoriented knowledge and can be useful for managers, independent experts and other stakeholders.

The findings suggest that companies should strengthen their learning and innovation orientation to improve business performance. This is the first study that in the two observed periods investigated the interrelationships between learning orientation, innovativeness and business performance in Croatian companies. Among the identified implications the evidence has been singled out that those found in Croatian companies may result in different relationships in other economies and should be explored in future studies.sm 


\section{References}

Acs, Z. J., Audretsch, D.B., \& Lehmann, E. E. (2013). The knowledge spillover theory of entrepreneurship. Small Business Economics, 41 (4), 757-774. https://doi.org/10.1007/s11187-013-9505-9

Alegre, J., \& Chiva, R. (2013). Linking Entrepreneurial Orientation and Firm Performance: The Role of Organizational Learning Capability and Innovation Performance. Journal of Small Business Management, 51 (4), 491-507. https://doi.org/10.1111/jsbm.12005

Aziz, N. A., \& Omar, N. A. (2013). Exploring the effect of internet marketing orientation, learning orientation and market orientation on innovativeness and performance: SME (Exporters perspectives). Journal of Business Economics and Management, 14 (1), 257-278. https://doi.org/10.3846/16111699.2011.645865

Baker, W. E., \& Sinkula, J. M. (1999). The synergistic effect of market orientation and learning organization and organizational performance. Journal of the Academy of Marketing Science, 27 (3), 411-427. https://doi.org/10.1177/0092070399274002

Baregheh, A., Rowley, J., \& Sambrook. S. (2009). Towards a multidisciplinary definition of innovation. Management Decision, 47 (8), 1323-1339. https://doi.org/10.1108/00251740910984578

Beneke, J., Blampied, S., Dewar, N., \& Soriano, L. ( 2016). The impact of market orientation and learning orientation on organisational performance. Journal of Research in Marketing and Entrepreneurship, 18 (1), 90-108. https://doi.org/10.1108/JRME-06-2015-0033

Calantone, R. J., Cavusgil, S. T., \& Zhao, Y. (2002). Learning orientation, firm innovation capability, and firm performance. Industrial Marketing Management, 31 (6), 515-524. https://doi.org/10.1016/S0019-8501(01)00203-6

Chandler, G. N., \& Lyon, D.W. (2009). Involvement in Knowledge-Acquisition Activities by Venture Team Members and Venture Performance. Entrepreneurship Theory and Practice, 33 (3), 571-592. https://doi.org/10.1111/j.1540-6520.2009.00317.x

Cosenz, F., \& Noto, G. (2018). Fostering entrepreneurial learning processes through Dynamic Start-up business model simulators. The International Journal of Management Education, 6 (3), 468-482. https://doi.org/10.1016/j.jime.2018.08.003

Damanpour, F., (1991). Organizational Innovation: A MetaAnalysis Of Effects Of Determinants and Moderators. Academy of Management Journal, 34 (3), 555-590. https://doi.org/10.5465/256406

D’Angelo, A., \& Presutti, M. (2019). SMEs international growth: The moderating role of experience on entrepreneurial and learning orientations. International Business Review, 28 (3), 613-624. https://doi.org/10.1016/i.ibusrev.2018.12.006

Day, G.S. (1994). The capabilities of market-driven organizations. Journal of Marketing, 58 (4), 37-52. https://doi.org/10.1177/002224299405800404

Dülger, M., Alpay, G., Yılmaz, C., \& Bodur, M. (2014). How do learning orientation and strategy yield innovativeness and superior firm performance? South African Journal of Business Management, 45 (2), 35-50. https://doi.org/10.4102/sajbm.v45i2.123
Goh, S. C., Elliott, C., \& Quon, T. K. (2012). The relationship between learning capability and organizational performance: A meta-analytic examination. The Learning Organization, 19 (2),92-108. https://doi.org/10.1108/09696471211201461

Ismail, M. D., Hamid, R. A., Senik, Z. C., Othman, A.S., \& Juhdi, N. H. (2018). SMEs' Export Performance: The Effect of Learning Orientation and Innovativeness. Jurnal Pengurusan, 54, 3-14. https://doi.org/10.17576/pengurusan-2018-54-01

Hakala, H. (2013). Entrepreneurial and learning orientation: effects on growth and profitability in the software sector. Baltic Journal of Management, 8 (1), 102-118. https://doi.org/10.1108/17465261311291687

Huan, N. Q., Phong, V. T., \& Giang, L. H. (2020). The Relationship Between Market Orientation, Learning Orientation and Business Model Innovation: A Case Study Of Restaurants - Hotels in Ho Chi Minh City. British Journal of Marketing Studies, 8 (3), 12-20. https://doi.org/10.37745/bjms/vol8.no3.pp12-20.2020

Hult, G. T. M., Hurley, R. F., \& Knight, G. A. (2004). Innovativeness: Its antecedents and impact on business performance. Industrial Marketing Management, 33 (5), 429-438. https://doi.org/10.1016/j.indmarman.2003.08.015

Hurley, R. F., \& Hult, G. T. M. (1998). Innovation, market orientation, and organizational learning: an integration and empirical examination. Journal of Marketing, 62(3),42-54. https://doi.org/10.1177/002224299806200303

Hussain, J., Shah, F.A., \& Khan, M.A. (2016). Does Organizational Learning Orientation Matter? Investigating the Impact of Learning Orientation on SMES Performance. Sarhad Journal of Management Sciences, 2 (2), 128-138. https://doi.org/10.31529/sjms.2016.2.2.3

Ismail, M. D., Hamid, R. A., Senik, Z. C., Othman, A. S. \& Juhdi, N. H. (2018). SMEs' Export Performance: The Effect of Learning Orientation and Innovativeness. Jurnal Pengurusan, 54, 3-14. https://doi.org/10.17576/pengurusan-2018-54-01

Jiménez-Jiménez, D., \& Cegarra-Navarro, J. G. (2007). The performance effect of organizational learning and market orientation. Industrial Marketing Management, 36 (6), 694-708. https://doi.org/10.1016/j.indmarman.2006.02.008

Kharabsheh, R. A., Jarrar, K., \& Simeonova, B. (2015). The impact of competitive strategies on responsive market orientation, proactive market orientation, learning orientation and organizational performance. Journal of Strategic Marketing, 23 (5), 423-435. https://doi.org/10.1080/0965254X.2014.970217

Keskin, H. (2006). Market orientation, learning orientation and innovation capability in SMES: an extended model. European Journal of Innovation Management, 9, (4), 396-417. https://doi.org/10.1108/14601060610707849

Koryak, O., Mole, K. F., Lockett, A., Hayton, J. C., Ucbasaran, D., \& Hodgkinson, G. P. (2015), Entrepreneurial leadership, capabilities and firm growth. International Small Business Journal: Researching Entrepreneurship, 33 (1), 89-105. https://doi.org/10.1177/0266242614558315 
Lee, T. S., \& Tsai, H. J. (2005). The effects of business operation mode on market orientation, learning orientation and innovativeness. Industrial Management \& Data Systems, 105 (3), 325-348. https://doi.org/10.1108/02635570510590147

Lin, C., Peng, C., \& Kao, D. T. (2008). The innovativeness effect of market orientation and learning orientation on business performance. International Journal of Manpower, 29 (8), 752 -772. https://doi.org/10.1108/01437720810919332

Lumpkin, G. T., \& Lichtenstein, B. B. (2005). The Role of Organizational Learning in the Opportunity-Recognition Process. Entrepreneurship Theory and Practice, 29 (4), 451- 472. https://doi.org/10.1111/j.1540-6520.2005.00093.x

Mahmoud, M. A., Blankson, C., Owusu-Frimpong, N., Nwankwo, S., Tran P., \& Trang, T. P. (2016). Market orientation, learning orientation and business performance. International Journal of Bank Marketing, 34 (5), 623-648. https://doi.org/10.1108/IJBM-04-2015-0057

Michna, A. (2009). The Relationship Between Organizational Learning and SME Performance in Poland. Journal of European Industrial Training, 33 (4), 356-370. https://doi.org/10.1108/03090590910959308

Nasution, H. N., Mavondo, F. T., Matanda, M. J., \& Ndubisi, N. O. (2011). Entrepreneurship: Its relationship with market orientation and learning orientation and as antecedents to innovation and customer value, Industrial marketing management, 40 (3), 336-345. https://doi.org/10.1016/j.indmarman.2010.08.002

Nguyen T. D., \& Barrett, N. J. (2006). The KnowledgeCreating Role of the Internet in International Business: Evidence from Vietnam. Journal of International Marketing, 14 (2), 116-147. https://doi.org/10.1509/jimk.14.2.116

Nurhasanah, N., \& Murwatiningsih, M. (2018). The influence of market orientation, learning orientation, innovation and competitive advantage to improve marketing performance, Management Analysis Journal, 7(4), 458-468. https://doi.org/10.15294/maj.v7i4.25637

Nybakk, E. (2012). Learning orientation, innovativeness and financial performance in traditional manufacturing firms: a higher-order structural equation model. International Journal of Innovation Management, 16 (5), 28. https://doi.org/10.1142/S1363919612003873

OECD/Eurostat (2005). Oslo Manual - Guidelines for collecting and interpreting innovation data 3rd Edition, OECD Publishing, Paris, France.

Phorncharoen, I. (2020). Influence of market orientation, learning orientation, and innovativeness on operational performance of real estate business. International Journal of Engineering Business Management, 12, 111.

$$
\text { https://doi.org/10.1177/1847979020952672 }
$$

Rahab, R. (2012). Innovativeness Model Of Small And Medium Enterprises Based On Market Orientation and Learning Orientation: Testing Moderating Effect Of Business Operation Mode. Procedia Economics and Finance, 4, 97-109. https://doi.org/10.1016/S2212-5671(12)00325-5
Real, J. C., Roldán, J. L., \& Leal, A. (2014). From entrepreneurial orientation and learning orientation to business performance: analysing the mediating role of organizational learning and the moderating effects of organizational size, British Journal of Management, 25 (2), 186-208. https://doi.org/10.1111/j.1467-8551.2012.00848.x

Rhee, J., Park, T., \& Lee, D. H. (2010). Drivers of innovativeness and performance for innovative SMEs in South Korea: Mediation of learning orientation. Technovation, 30 (1), 65-75. https://doi.org/10.1016/j.technovation.2009.04.008

Salim, I. M., \& Sulaiman, M. (2011). Organizational Learning, Innovation and Performance: A Study of Malaysian Small and Medium Sized Enterprises. International Journal of Business and Management, 6 (12), 118-125. https://doi.org/10.5539/ijbm.v6n12p118

Sanzo, M. J., Santos, M. L., García, N., \& Trespalacios, J. A. (2012). Trust as a moderator of the relationship between organizational learning and marketing capabilities: Evidence from Spanish SMEs. International Small Business Journal, 30 (6), 700-726. https://doi.org/10.1177/0266242611418907

Senge, P. M. (1990). The Fifth Discipline: The Art \& Practice of The Learning Organization, Doubleday, Inc.

Slater, S. F., \& Narver, J. C. (1994). Does Competitive Environment Moderate the Market Orientation-

Performance Relationship? Journal of Marketing, 58 (1), 46-55.

https://doi.org/10.1177/002224299405800104

Slater, S. F., \& Narver, J. C. (1995). Market Orientation and the Learning Organization, Journal of Marketing, 59 (3),63-74. https://doi.org/10.1177/002224299505900306

Sinkula, J. M., Baker, W. E., \& Noordewier, T. (1997). A Framework for Market-Based Organizational Learning: Linking Values, Knowledge, and Behavior. Journal of the Academy of Marketing Science, 25 (4), 305-318. https://doi.org/10.1177/0092070397254003

Stelmaszczyk, M. (2020). How Absorptive Capacity and Organisational Learning Orientation Interact to Enable Innovation Capability? An Empirical Examination. Entrepreneurial Business and Economics Review, 8 (1), 7-32.

https://doi.org/10.15678/EBER.2020.080101

Suliyanto, S. \& Rahab, R. (2012). The role of market orientation and learning orientation in improving innovativeness and performance of small and medium enterprises. Asian Social Science, 8 (1), 134-145. https://doi.org/10.5539/ass.v8n1p134

Šlogar, H., \& Bezić, H. (2020). The relationship between innovative orientations and business performance in companies. Ekonomska misao i praksa, 29 (1), 57-76. https://doi.org/10.22598/pi-be/2020.14.2.71

Tajeddini, K., \& Mueller, S. L. (2009). Entrepreneurial characteristics in Switzerland and the UK: A comparative study of techno-entrepreneurs. Journal of International Entrepreneurship, 7 (1), 1-25. https://doi.org/10.1007/s10843-008-0028-4

Ullah, Z., Mushtaq, F., Puhakka, V., \& Iqbal, N. (2020). Learning orientation and market orientation: the mediating role of employees' absorptive capabilities: an abstract, Marketing Opportunities and Challenges in a Changing Global Marketplace, 459-460. https://doi.org/10.1007/978-3-030-39165-2 188 
Vega Martinez, J. E., Martinez Serna, M. C., \& Montoya, N. P. (2020). Dimensions of learning orientation and its impact on organizational performance and competitiveness in SME's. Journal of Business Economics and Management, 21 (2), 395-420. https://doi.org/10.3846/jbem.2020.11801

Vij, S. \& Farooq, R., (2014). Multi-Group Moderation Analysis for Relationship between Knowledge Sharing Orientation and Business Performance. International Journal of Knowledge Management, 10 (3), 36-53. https://doi.org/10.4018/ijkm.2014070103

\section{$\bowtie$ Correspondence}

\section{Helena Šlogar}

Libertas International University

Trg John F. Kennedy 6b, 10000, Zagreb, Croatia

E-mail: hslogar@libertas.hr
Wang, C. L. (2008). Entrepreneurial orientation, learning orientation, and firm performance. Entrepreneurship Theory and Practice, 32 (4), 635-657.

https://doi.org/10.1111/j.1540-6520.2008.00246.x 